\title{
Human papillomavirus detection and typing using a nested-PCR-RFLP assay
}

\begin{abstract}
Background: It is clinically important to detect and type human papillomavirus (HPV) in a sensitive and specific manner. Objectives: Development of a nested-polymerase chain reaction-restriction fragment length polymorphism (nested-PCR-RFLP) assay to detect and type HPV based on the analysis of L1 gene. Methods: Analysis of published DNA sequence of mucosal HPV types to select sequences of new primers. Design of an original nested-PCR assay using the new primers pair selected and classical MY09/11 primers. HPV detection and typing in cervical samples using the nested-PCR-RFLP assay. Results: The nested-PCR-RFLP assay detected and typed HPV in cervical samples. Of the total of 128 clinical samples submitted to simple PCR and nested-PCR for detection of HPV, 37 (28.9\%) were positive for the virus by both methods and 25 samples were positive only by nested-PCR (67.5\% increase in detection rate compared with single PCR). All HPV positive samples were effectively typed by RFLP assay. Conclusion: The method of nested-PCR proved to be an effective diagnostic tool for HPV detection and typing.
\end{abstract}

Keywords: DNA probes, HPV; polymerase chain reaction; polymorphism, restriction; fragment length.

\section{INTRODUCTION}

Cancer of the uterine cervix is one of the most important diseases among women worldwide, with approximately 500,000 new cases and 260,000 deaths per year. ${ }^{1}$ In Brazil, the National Cancer Institute (INCA) estimates 18,430 new cases for this current year. ${ }^{2}$

The infection with certain types of human papillomavirus (HPV) is recognized as a causal factor required for the development of cervical cancer. ${ }^{3}$ This virus belongs to the Papillomaviridae family and is further classified in 12 Papillomavirus genera infecting different animal species. Five of this genera (alfa, beta, gama, mu and nu) can infect humans and are classified according to the oncogenic potential in high $(16,18,26,30,31$, $33,34,35,39,45,51,52,53,56,58,59,66,67$, $68,69,70,73,82)$ and low-risk types $(6,11$, $13,32,42,43,44,54,55,61,71,72,74,81,83$, 84, candHPV85). ${ }^{4}$

Molecular methods to detect HPV-DNA (mainly the oncogenic types) have already been developed and are currently used in clinical laboratories. The precise identifica- tion of viral types is essential for clinical assessment and monitoring of cervical diseases in women. ${ }^{5}$ The Hybrid Capture II (Qiagen) is a method widely used in many countries and is able to detect 18 HPV types. This method is based on a non-radioactive signal amplification method that uses two sets of RNA probes, one for low-risk $(6,11,42,43$ and 44) and another for high-risk types (16, $18,31,33,35,39,45,51,52,56,58,59$ and 68). Despite being approved by the Food and Drug Administration (FDA), Hybrid Capture II has some important limitations, as it does not detect some HPV types, does not identify the specific type of HPV, is less sensitive than PCR and presents cross-reactivity of the RNA probes (for low and high risk), reducing the clinical relevance of a positive result. ${ }^{6-10}$

Alternatively, there are several PCR methods to detect HPV-DNA. The use of primers targeted to highly conserved consensus sequences of the virus (mainly in the L1 region) allows simultaneous amplification of a large number of mucosal HPV types. The majority of the PCR methods use single PCR
Authors

Janaina Coser $^{1}$

Thaís da Rocha Boeira ${ }^{2}$ André Salvador Kazantzi Fonseca $^{3}$

Nilo Ikuta ${ }^{4}$

Vagner Ricardo Lunge ${ }^{4}$

${ }^{1} \mathrm{MSc}$; Professor,

Postgraduate Program in Genetics and Molecular Diagnosis, Universidade Luterana do Brasil (ULBRA), Canoas, RS, Brazil, and Universidade de Cruz Alta (UNICRUZ), Cruz Alta, RS, Brazil ${ }^{2} \mathrm{MSc}$; Technical Manager, Simbios Biotecnologia,

Canoas, RS, Brazil

${ }^{3} \mathrm{MSc}$; Researcher, Simbios Biotecnologia, Canoas, RS, Brazil

${ }^{4} \mathrm{PhD}$; Professors,

Postgraduate Program in Genetics and Molecular Diagnosis, ULBRA,

Canoas, RS, Brazil; Simbios Biotecnologia, Canoas, RS, Brazil

Submitted on: 02/01/2011 Approved on: 05/11/2011

Correspondence to: Vagner Ricardo Lunge ULBRA

Laboratório de

Diagnóstico Molecular Avenida Farroupilha, 8001

Prédio 22 - sala 312

Bairro São José

92425-900, Canoas, RS,

Brazil

lunge@ulbra.br

Financial Support: Simbios Biotecnologia.

We declare no conflict of interest.

(C)2011 Elsevier Editora Ltda All rights reserved. 
amplification with two pairs of consensus primers: MY09/11 or GP5+/6+. ${ }^{11,12}$ Primers pair MY09/11 has been largely used in clinical and epidemiological studies. ${ }^{13-16}$ One of the main advantages of this primers combination is the possibility of determining the HPV type using different procedures: restriction fragment length polymorphism (RFLP) assay, sequencing, and micro-array technology. ${ }^{10,17-20}$

Nested-PCR techniques have proven to be more sensitive for the detection of HPV than PCR methods based on only one amplification reaction. ${ }^{21,22}$ A nested-PCR method using MY09/11 and GP5+/6+ primers has been used in large epidemiological studies for the sensitive detection of HPV in cervical samples. ${ }^{16}$ However, the nested-PCR techniques previously described require additional sequencing or hybridization procedures to accurately identify the HPV type. ${ }^{21,23}$ This study aimed to develop and validate a highly sensitive nested-PCR-RFLP methodology for HPV detection and typing easily applied in limited-resource laboratories.

\section{MATERIALS AND METHODS}

The project "Evaluation of the use of HPV-DNA detection in screening for precancerous lesions and cervical neoplasia in an urban center in Southern Brazil" was approved by the Ethics Committee of Universidade de Cruz Alta under the protocol number 078.0.417-09.

\section{Clinical samples}

The first group of samples included a panel of 44 clinical samples, positive and negative for HPV, previously analyzed in a molecular diagnostic laboratory. These samples were previously detected by the PCR-RFLP method and presented the following HPV types: $6,11,16,33,53,54,56,58,61$, 62, 66, 70 (CP 141), 83 (MM7) and 84 (MM8). The second group included 84 samples obtained prospectively from women seeking routine care in a screening program for cervical cancer in a public health service in southern Brazil.

All the samples were collected by scraping the ecto and endocervix with individual brushes. Each brush was packed in a modified buffer solution (EDTA pH 8.0 0.01 M, SDS $0.03 \mathrm{M}$ ) and conserved at $-20^{\circ} \mathrm{C}$ until analysis.

\section{HPV DNA sequences analysis}

Published DNA sequences of the main mucosal HPV types $(6,11,13,16,18,26,30,31,32,33,34,35,39,40,42,43,44$, $45,51,52,53,54,56,58,59,61,66,67,68,69,70,71,72$, $73,74,81,82,83,84,90$, cand 85 , cand 86 , cand 87 , cand 89 , cand91 - all of them classified in the Alpha-papillomavirus genus) were obtained from the GenBank database (http:// www.ncbi.nlm.nih.gov/Genbank/). These sequences were edited and aligned using EditSeq and MegAlign softwares from the DNAstar package (Lasergene Inc., USA), respectively. DNA segments of the L1 gene were selected and compiled in a document file for primer design. The PCR primers pair was selected directly in the aligned sequences and the hybridization temperature was estimated using the PrimerSelect software also from the DNAstar package (Lasergene Inc., USA).

\section{DNA extraction}

Total DNA of the clinical samples was purified by a standard silica/GuSCN-based procedure. ${ }^{24}$ Briefly, $100 \mu \mathrm{L}$ of the liquid sample was added to $900 \mu \mathrm{L}$ of lysis buffer (GuSCN $5 \mathrm{M}$, Tris-HCl 0.1 M, EDTA $0.5 \mathrm{M}$ and Triton $\mathrm{X}-100)$ and then incubated at room temperature for $10 \mathrm{~min}$. After, $20 \mu \mathrm{L}$ of silica suspension was added to each sample, mixed and centrifuged at 10,000 rpm for $30 \mathrm{sec}$. The pellet was washed twice with $1.0 \mathrm{~mL}$ washing buffer (GuSCN $5 \mathrm{M}$ and Tris- $\mathrm{HCl} 0.1 \mathrm{M}$ ), twice with $75 \%$ ethanol and once with acetone. The silica suspension was dried at $56-60^{\circ} \mathrm{C}$ for $10 \mathrm{~min}$. DNA was eluted with 50 $\mu \mathrm{L}$ of TE buffer and the solution was separated from the silica particles centrifuging at 10,000 rpm for $3 \mathrm{~min}$ to use as template in PCR reaction.

\section{HPV detection by PCR and nested-PCR assays}

HPV-DNA was analyzed by PCR (with one amplification reaction) and nested-PCR assays. PCR was carried out in a total volume of $30 \mu \mathrm{L}$ using $2 \mu \mathrm{L}$ of template DNA, $1 \mathrm{X}$ PCR buffer (10 mM Tris- $\mathrm{HCl} \mathrm{pH} \mathrm{8.5,50} \mathrm{mM} \mathrm{KCl),} 1.5 \mathrm{mM}$ $\mathrm{MgCl}_{2}, 0.0625 \mathrm{mM}$ of each deoxynucleotide triphosphate (dATP, dTTP, dCTP, dGTP), $0.5 \mu \mathrm{M}$ of each consensus primers MY09/MY11 and 1.6 U of Taq DNA polymerase (Cenbiot Enzimas, RS, Brazil). Thermal cycling was performed in a PE Applied Biosystems 9700 Sequence Detector System with the following program: $4 \mathrm{~min}$ at $95^{\circ} \mathrm{C}, 35$ cycles of $30 \mathrm{sec}$ at $94^{\circ} \mathrm{C}, 30 \mathrm{sec}$ at $56^{\circ} \mathrm{C}$ and $30 \mathrm{sec}$ at $72^{\circ} \mathrm{C}$, with final extension step at $72^{\circ} \mathrm{C}$ for $8 \mathrm{~min}$.

Nested-PCR assay was performed in two consecutive amplification reactions. The first reaction was carried out in a total volume of $30 \mu \mathrm{L}$ using $2 \mu \mathrm{L}$ of template DNA, 1X PCR buffer (10 mM Tris- $\mathrm{HCl} \mathrm{pH} \mathrm{8.5,} 50 \mathrm{mM} \mathrm{KCl})$, $1.5 \mathrm{mM} \mathrm{MgCl}, 0.0625 \mathrm{mM}$ of each deoxynucleotide triphosphate (dATP, dTTP, dCTP, dGTP), $0.5 \mu \mathrm{M}$ of each primer, $1 \mathrm{U}$ of Taq DNA polymerase (Cenbiot Enzimas, RS, Brazil). Amplification was performed in a PE Applied Biosystems 9.700 with this program: $1 \mathrm{cycle}$ at $95^{\circ} \mathrm{C}$ for $3 \mathrm{~min}$ and $20 \mathrm{cycles}$ at $95^{\circ} \mathrm{C}$ for $20 \mathrm{sec}, 40^{\circ} \mathrm{C}$ for $40 \mathrm{sec}$ and $72^{\circ} \mathrm{C}$ for $1 \mathrm{~min}$, followed by a final extension cycle at $72^{\circ} \mathrm{C}$ for $5 \mathrm{~min}$. The second reaction was also carried out in a volume of $30 \mu \mathrm{L}$ using $2 \mu \mathrm{L}$ of amplified DNA, $0.25 \mu \mathrm{M}$ of the primers (MY09/11) and the same reagents and concentrations described above. Thermal cycling was performed in the same equipment with the following steps: 1 cycle at $95^{\circ} \mathrm{C}$ for $3 \mathrm{~min}, 35 \mathrm{cycles}$ at $95^{\circ} \mathrm{C}$ for $20 \mathrm{sec}$, $55^{\circ} \mathrm{C}$ for $40 \mathrm{sec}$ and $72^{\circ} \mathrm{C}$ for $1 \mathrm{~min}$, and a final extension cycle at $72^{\circ} \mathrm{C}$ for $5 \mathrm{~min}$. 
Positive and negative samples were added as controls in all experiments for quality control. The amplified DNA products and molecular weight markers were then submitted to electrophoresis in $10 \%$ polyacrylamide gels at $65 \mathrm{~V}$ for 1 hour. Each gel was stained with silver nitrate and positive/negative results were evaluated based on the presence of fragments of the expected size ( 450 bp).

\section{HPV typing by RFLP assay}

All HPV positive samples were typed by RFLP analysis. Each restriction reaction was performed separately in a final volume of $10 \mu \mathrm{L}$, using $2 \mu \mathrm{L}$ of MY09/11 PCR product, $1 \mu \mathrm{L}$ of $10 \mathrm{X}$ recommended restriction buffer and 10 units of the following restriction endonucleases: Pst (New England Biolabs, USA), HaeIII (New England Biolabs, USA), DdeI (New England Biolabs, USA), RsaI (Promega, USA) and HinfI (New England Biolabs, USA), according to the manufacturer's instructions. Reactions were carried out at $37^{\circ} \mathrm{C}$ for 1 hour. Digested products were separated on $10 \%$ polyacrylamide gels by electrophoresis together with a 50 bp DNA molecular weight marker (Promega, USA), and after stained with silver nitrate.

\section{Confirmation of RFLP analysis by sequencing}

PCR products were sequenced to confirm the RFLP results. Forward and reverse sequencing reactions were carried out using 15 to 30 ng of template DNA from PCR amplimers, 3.2 pmol of the MY09 and MY11 primers (respectively) and $4 \mu \mathrm{L}$ of reagent BigDye Terminator v3.1 Cycle Sequencing (Applied Biosystems Inc., Norwalk, CT, USA) in a final volume of $20 \mu \mathrm{L}$. The sequencing rounds were performed in the thermocycler Veriti 96 (Applied Biosystems Inc., Norwalk, CT, USA) with the initial step of $95^{\circ} \mathrm{C}$ for $3 \mathrm{~min}$ followed by 40 cycles of $95^{\circ} \mathrm{C}$ for $10 \mathrm{sec}$ and $60^{\circ} \mathrm{C}$ for $240 \mathrm{sec}$. The samples were purified by ethanol/EDTA/sodium acetate protocol and the precipitated DNA products were diluted in $10 \mu \mathrm{L}$ of formamide $\mathrm{Hi}-\mathrm{Di}$, denatured $\left(95^{\circ} \mathrm{C}\right.$ for $\left.2 \mathrm{~min}\right)$ and injected in the automated DNA sequencing ABI 3130 XL Genetic Analyzer (Applied Biosystems Inc., Norwalk, CT, USA). The sequence data were collected using the Data Collection program v1.0.1 with the parameters Dye Set "Z". Quality analysis was performed using the Sequencing Analysis v.5.3.1 software by evaluating the main technical parameters as raw data, electropherogram and quality value of sequenced bases (Applied Biosystems Inc., Norwalk, CT, USA). The nucleotide sequences of the same amplicon (primers sense and antisense) were edited and assembled using SeqMan software (DNAStar, Madison, Wisconsin, USA). The nucleotide sequences of the samples were aligned using the MegAlign program (DNAStar, Madison, Wisconsin, USA) and types were deduced from the phylogenies generated by the program itself. Further, data obtained were compared with sequences available in GenBank database (www.ncbi.nlm.nih.gov) using BLAST tool.

\section{RESULTS}

\section{Primers and nested-PCR-RFLP design}

After alignment of the L1 HPV sequences obtained in GenBank, conserved sequence regions (upstream to MY09 primer and downstream to MY11 primer) were selected and analyzed in PrimerSelect software (Lasergene Inc., USA). Considering a fitness combination for a primers pair and detection of all HPV types, the following sequences were selected: 5'-CAA WTR TTY AAT AAR CCW TAT TGG-3' (primer SB01) and 5'-AAA AAY TTY CGW CCM ARR GG-3' (primer SB02). PCR product is approximately $495 \mathrm{bp}$ for the majority of HPV types. Using this primers pair, a novel detection and typing procedure based on nested-PCR-RFLP assay was designed. The whole procedure consisted in a first amplification by PCR with low stringent condition (annealing temperature of $40^{\circ} \mathrm{C}$ ), a second amplification by PCR using MY09/11 primers pairs (nested-PCR) and typing by restriction fragment length polymorphism (RFLP) assay.

This procedure was used to detect and type HPV in DNA samples extracted from two previously analyzed clinical samples with positive results for types 6 and 16 . In both samples, the expected $\sim 450$ bp fragment of L1 gene was successfully amplified by nested-PCR assay. Further, RFLP assay demonstrated the same pattern of the two types previously found (Figure 1). To confirm the specificity of the assay, the nested-PCR assay was also performed with DNA extracted from negative HPV cervical samples. HPV specific fragments were not detected.

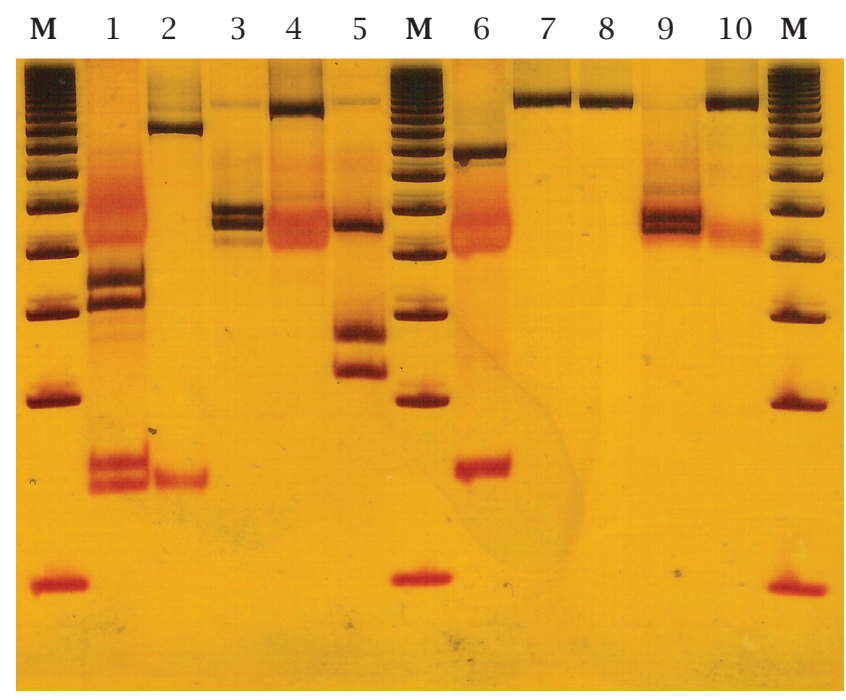

Figure 1: Restriction enzyme patterns of MY09/11 amplicon from HPV types 6 and 16. Lanes M, 50 bp ladder size marker; lanes 1 to 5, HPV 6 digested with Rsa I, Dde I, Hinf I, Pst I and Hae III; lanes 1 to 5, HPV 6 digested with Rsa I, Dde I, Hinf I, Pst I and Hae III. 


\section{Evaluation of the nested-PCR-RFLP assay with clinical samples}

The nested-PCR-RFLP assay was compared to MY09/11 PCR assay using two groups of cervical samples. The first group had 44 previously analyzed cervical samples of a service laboratory, $24 \mathrm{HPV}-\mathrm{DNA}$ positive and 20 negative by MY09/11 PCR. A total of 36 samples were positive and 8 negative using the nested-PCR assay. All the 24 positive samples by MY09/11 PCR were also positive by nested-PCR. In addition, 12 samples were exclusively positive for HPV by the nested-PCR assay (Table 1). Afterwards, 84 consecutively collected cervical samples (second group), obtained from women who underwent routine examination for cervical cancer screening in a public health service in a city (Cruz Alta) of Rio Grande do Sul State (Southern Brazil), were analyzed by both procedures (MY09/11 PCR and nested-PCR assays) in a blind fashion experiment. Again, all the positive samples by PCR (13) were also positive in the nested-PCR and other 13 samples were exclusively HPV positive using the nested-PCR assay (Table 1).

Table 1. Results of HPV-DNA detection using MY09/11 PCR in comparison to nested-PCR assays in two groups of cervical samples (pre-analyzed and prospectively collected)

\begin{tabular}{lccc}
\hline & \multicolumn{3}{c}{ MY09/11 PCR } \\
\cline { 2 - 4 } Nested-PCR & $\begin{array}{c}\text { Positive } \\
\mathbf{n = 3 7}\end{array}$ & $\begin{array}{c}\text { Negative } \\
\mathbf{n = 9 1}\end{array}$ & $\begin{array}{c}\text { Total } \\
\mathbf{n}=\mathbf{1 2 8}\end{array}$ \\
\hline First group & & & \\
Positive & 24 & 12 & 36 \\
Negative & 0 & 8 & 8 \\
Total & 24 & 20 & 44 \\
\hline Second group & & & \\
Positive & 13 & 13 & 26 \\
Negative & 0 & 58 & 58 \\
Total & 13 & 71 & 84 \\
\end{tabular}

In the analysis by RFLP assay, 23 different HPV types were identified (12 high-risk and 11 low-risk). Importantly, two high-risk types (HPV 45 and HPV 73) and three low-risk types (HPV 44, HPV 71 and HPV 81) were detected only by nested-PCR-RFLP assay (Table 2). Mixed infections were identified in 14 samples and the HPV types (two in all samples) of each case were efficiently discriminated by the RFLP assay. DNA sequencing was consistent with the pattern obtained by RFLP assay in all cases with only one HPV type in the sample. In the 14 mixed infection cases, DNA sequencing identified one of the types detected by RFLP assay.

\section{DISCUSSION}

The wide variation of HPV types and the occurrence of multiple infections by this virus require reliable methods for HPV detection and typing. These methodologies are essential for patient management by the clinician and even epidemiological studies. In the near future, HPV detection and typing will also be important in the screening and monitoring of women that use specific vaccines or therapies. ${ }^{25}$

HPV detection is based on the analysis of the viral DNA by different methods (hybrid-capture, PCR, hybridization). In the PCR assays currently used, consensus primers (MY09/11, GP5+/6+, PGMY, SPF10) are targeted to the highly conserved L1 region and detect different HPV types. ${ }^{12,26-28}$ Previous studies have already demonstrated that the use of primers pair MY09/11 and GP5/GP6 in a nested-PCR assay increases the sensitivity of HPV detection compared with PCR assay. ${ }^{18,21,25,29,30}$ However, all of these studies used an additional sequencing and/or hybridization step of the amplification product for HPV typing. ${ }^{23}$

In this study, the development of a methodology based on nested-PCR technique, using an external primers pair in a first amplification and the "classical" primers pair MY09/11 in a second reaction, enabled the sensitive HPV detection in cervical samples. This was possible with the design of a new degenerated primers pair external to the region of the MY09/11 amplified product and the use of low stringent condition (annealing temperature of $40^{\circ} \mathrm{C}$ ),

Table 2. HPV types identified by RFLP in the positive samples after amplification with MY09/11 PCR and nested-PCR assays

\begin{tabular}{lcc}
\hline & High-risk types (n) & Low-risk types (n) \\
\hline MY09/11 PCR & $16(6)^{\mathrm{b}}, 18(1)^{\mathrm{b}}, 33(6)^{\mathrm{b}}, 35(1)$, & $6(2)^{\mathrm{b}}, 11(4)^{\mathrm{b}}, 42(2), 54(5)^{\mathrm{b}}$, \\
and nested-PCR $(\mathrm{n}=37)$ & $52(2)^{\mathrm{b}}, 53(3)^{\mathrm{b}}, 56(2)^{\mathrm{b}}$, & $61(2)^{\mathrm{b}}, 62(1), 83(1)^{\mathrm{b}}, 84(4)^{\mathrm{b}}$ \\
& $58(2)^{\mathrm{b}}, 66(4)^{\mathrm{b}}, 70(1)$ & \\
\hline Only by nested-PCR $(\mathrm{n}=25)$ & $16(2)^{\mathrm{b}}, 35(1), 45^{\mathrm{a}}(4), 52(1)$, & $6(1)^{\mathrm{b}}, 11(1), 42(1), 44^{\mathrm{a}}(1)$, \\
& $53(1)^{\mathrm{b}}, 58(2), 66(1), 70(3), 73^{\mathrm{a}}(2)^{\mathrm{b}}$ & $54(2), 62(1), 71^{\mathrm{a}}(1)^{\mathrm{b}}, 81^{\mathrm{a}}(1)^{\mathrm{b}}, 84(1)$ \\
\hline
\end{tabular}

${ }^{a} \mathrm{HPV}$ types identified only by nested-PCR; ${ }^{\mathrm{b}} \mathrm{HPV}$ types found in the 14 samples with mixed infection. 
aiming the amplification of all cervical HPV types. In the analysis of pre-selected clinical samples (mostly positive) and cervical samples of a women group (mostly negative), an estimated $67.5 \%$ of increase in the rate of HPV detection was obtained as compared to MY09/11 PCR. Husnjak et al., ${ }^{31}$ comparing different techniques of PCR to detect HPV DNA in cervical samples, has reported an increase of $38.8 \%$ detection rate using the method of nested-PCR (GP5/GP6) compared to single PCR amplification. Furthermore, in our study, all the 37 positive samples by PCR with MY09/11 primers were also detected by the nested-PCR assay (there were no cases of HPV detected by MY09/11 PCR and not detected by nested-PCR).

Considering PCR with MY09/11 primers as the "gold standard", the clinical sensitivity and specificity were $100 \%$ and $72 \%$, respectively. But it is important to consider that PCR with MY09/11 primers has clearly a lower analytical sensitivity than the nested-PCR assay developed in our study and this is the probable reason for the low clinical specificity of the assay. Previous works have already demonstrated a higher analytical sensitivity for other nested-PCR assays. ${ }^{25,30}$ We further classified the samples into two groups (positive by both procedures versus positive only by nested-PCR) and observed different patterns of HPV types and frequency by RFLP and sequencing. Some types were detected only by nested-PCR, as for example the high-risk types 45 and 73 and the low-risk types 44,71 and 81 (Table 2). This reinforces that the samples positive only in the nested-PCR assay are probably not false-positive results, but due to the higher analytical sensitivity of this assay. Other studies have also used nested-PCR assays to maximize the detection of HPV in different populations. ${ }^{16,21,23,32}$

Besides the increase in the analytical sensitivity, another advantage of this new methodology is the possibility to perform HPV typing by RFLP assay, an easier and cheaper methodology than sequencing. In our study, the nested-PCR-RFLP assay detected precisely low $(11,42,44$, $54,62,70,81,84)$ and high-risk types $(16,18,33,35,45,52$, $53,58,73)$. All these results were confirmed by DNA sequencing. These findings are similar to those reported by Aedo et al., ${ }^{18}$ which identified 13 different types in samples tested with nested-PCR-RFLP in Chile. Similarly, Camara et al..$^{33}$ using the methodology of PCR-RFLP identified 13 viral types in women of the Distrito Federal, Brazil.

The methodology presented in this paper combines an easy and fast DNA extraction procedure, a sensitive nested-PCR amplification technique and a RFLP procedure that identify the main cervical HPV types. The procedure is suitable for the detection and characterization of HPV-DNA in public health programs to screen this virus in the population and would be also a useful tool for HPV epidemiological control, determining the circulating types in different geographical regions. Furthermore, it could be easily per- formed in limited-resource laboratories, not requiring additional sequencing or hybridization procedures (and all the equipment necessary) to accurately identify the HPV type.

\section{REFERENCES}

1. World Health Organization. Human Papillomavirus and HPV Vaccines: Technical Information for Policy-makers and Health Professionals. Geneva: WHO; 2007.

2. Ministério da Saúde 2009. Secretaria de Atenção à Saúde. Instituto Nacional de Câncer. Coordenação de Prevenção e Vigilância de Câncer. Estimativas 2010: Incidência de Câncer no Brasil. Rio de Janeiro: INCA. Available at: http://www.inca. gov.br/estimativa/2010/estimativa20091201.pdf. Accessed on Aug 2010.

3. Burd EM. Human papillomavirus and cervical cancer. Clin Microbiol Rev 2009; 16(1):1-17.

4. De Villiers EM, Fauquet C, Broker TR et al. Classification of papillomaviruses. Virology 2004; 324(1):17-27.

5. Arbyn M, Sasieni P, Meijer CJLM et al. Chapter 9: Clinical applications of HPV testing: A summary of meta-analyses. Vaccine 2006; 24(3):78-89.

6. Smits HL, Bollen LJ, Tjong-A-Hung SP et al. Intermethod variation in detection of human papilomavírus DNA in cervical smears. J Clin Microbiol 1995; 33(10):2631-6.

7. Cope JU, Hildesheim A, Schiffman $\mathrm{MH}$ et al. Comparison of the Hybrid Capture tube test and PCR for detection of human papillomavirus DNA in cervical specimens. J Clin Microbiol 1997; 35(9):262-5.

8. Castle PE, Schiffman M, Burk RD et al. Restricted cross-reactivity of Hybrid Capture 2 with nononcogenic human papillomavirus types. Cancer Epidemiol Biomarkers Prev 2002; 11(11):1394-9.

9. Poljak M, Marin IJ, Seme K et al. Hybrid Capture II HPV test detects at least 15 human papillomavirus genotypes not included in its current high-risk probe cocktail. J Clin Virol 2002; 25(3):89-97.

10. Molijn A, Kleter B, Quint W et al. Molecular diagnosis of human papillomavirus (HPV) infections. J Clin Virol 2005; 32(1):43-51.

11. Hubbard RA. Human papillomavirus testing methods. Arch Pathol Lab Med 2003; 127(8):940-5.

12. Gravitt PE, Coutléeb F, Iftnerc T et al. New Technologies in Cervical Cancer Screening. Vaccine 2008; 26(10):42-52.

13. Pizzighella S, Rassu M, Piacentin I et al. Polymerase chain reaction amplification and restriction enzyme typing as an accurate and simple way to detect and identify human papillomaviruses. J Med Microbiol 1993; 39(1):33-8.

14. Qu W, Jiang G, Cruz Y et al. PCR detection of human papillomavirus: comparison between MY09/MY11 and GP51/GP61 primer systems. J Clin Microbiol 1997; 35(6):1304-10.

15. Fernandes TAAM, Meissner RV, Bezerra LF et al. Human papillomavirus infection in women attended at a cervical cancer screening service in Natal, Brazil. Braz J Microbiol 2008; 39(3):573-8.

16. Lippman SA, Sucupira MCA, Jones HE et al. Prevalence, distribution and correlates of endocervical human papillomavirus types in Brazilian women. Int J STD \& AIDS 2010; 21(2):105-9.

17. Wanderlei-Silva D, Nobre M, Gonzaga RS et al. High quality DNA from human papillomavirus (HPV) for PCR/RFLPs. Braz Arch Biol Technol 2005; 48(1):37-40. 
18. Aedo S, Melo A, García P et al. Detección y tipificación de vírus papiloma humano en lesiones preneoplásicas del cuello uterino mediante PCR-RFLP. Rev Méd Chile 2007; 135(2):167-73.

19. Nobre RJ, Almeida LP, Martins TC. Complete genotyping of mucosal human papillomavirus using a restriction fragment length polymorphism analysis and an original typing algorithm. J Clin Virol 2008; 42(1):13-21.

20. Oliveira LHS, Ferreira MDPL, Augusto EF et al. Human papillomavirus genotypes in asymptomatic young women from public schools in Rio de Janeiro, Brazil. Rev Soc Bras Med Tropical 2010; 43(1):4-8.

21. Chaiwongkot A, Pientong C, Ekalaksananan T et al. evaluation of primers and PCR performance on HPV DNA screening in normal and low grade abnormal cervical cells. Asian Pacific J Cancer Prevention 2007; 8(2):279-282.

22. Winder DM, Ball SLR, Vaughan K et al. Sensitive HPV detection in oropharyngeal cancers. BMC Cancer 2009; 9(1):440-50.

23. Lee SH, Vigliotti VS, Vigliotti JS, Pappu S. Validation of human papillomavirus genotyping by signature DNA sequence analysis. BMC Clin Pathol 2009; 9(3):1-30.

24. Boom R, Sol CJA, Salimans M et al. Rapid and simple method for purification of nucleic acids. J Clin Microbiol 1990; 28(3):495-503.

25. Sotlar K, Diemer D, Dethleffs A. Detection and typing of human papillomavirus by e6 nested multiplex PCR. J Clin Microbiol 2004; 42(7):3176-84.

26. Jacobs MV, Snijders PJF, Voorhorst FJ et al. Reliable high risk HPV DNA testing by polymerase chain reaction: an intermethod and intramethod comparison. J Clin Pathol 1999; 52(7):498-503.
27. Gravitt PE, Peyton CL, Alessi TQ et al. Improved amplification of genital human papillomaviruses. J Clin Microbiol 2000; 38(1):357-61.

28. Hesselink AT, Van Ham MAPC, Heideman DAM et al. Comparison of GP5/6- PCR and SPF10-Line blot assays for detection of high-risk human papillomavirus in samples from women with normal cytology results who develop grade 3 cervical intraepithelial neoplasia. J Clin Microbiol 2008; 46(10):3215-21.

29. Remmerbach TW, Brinckmann UG, Hemprich A et al. PCR detection of human papillomavirus of the mucosa: comparison between MY09/11 and GP5+/6+ primer sets. J Clin Virol 2004; 30(4):302-8

30. Giovannelli L, Lama A, Capra G et al. Detection of Human Papillomavirus DNA in Cervical Samples: Analysis of the New PGMY-PCR Compared To the Hybrid Capture II and MYPCR Assays and a Two-Step Nested-PCR Assay. J Clin Microbiol 2004; 42(8):3861-4.

31. Husnjak K, Grce M, Magdic L et al. Comparison of five different polymerase chain reaction methods for detection of human papillomavirus in cervical cell specimens. J Virol Methods 2000; 88(2):125-34.

32. Carrillo A, Mohar A, Meneses A et al. Utilidad en la combinación de oligonucleótidos universales para la detección del vírus del papiloma humano en câncer cervicouterino y lesiones premalignas. Salud Púb Méx 2004; 46(1):7-15.

33. Camara GNL, Cerqueira DM, Oliveira APG et al. Prevalence of Human Papillomavirus types in women with pre-neoplastic and neoplastic cervical lesions in the Federal District of Brazil. Mem Inst Oswaldo Cruz 2003; 98(7):879-83. 